\title{
THE DEVELOPMENT OF CLASSROOM POLICIES THROUGH DISCUSSION BETWEEN TEACHERS AND STUDENTS
}

\author{
Kurniawan Yudhi Nugroho \\ Sultan Agung Islamic University \\ Email: kurniawan@unissula.ac.id \\ DOI: http://dx.doi.org/10.17509/bs_jpbsp.v16i2.4480
}

\begin{abstract}
This article presented the result in the interview and discussion between teacher and students aimed at revealing students' perception on the previous course program. Of the interview and discussion, it was observed that the previous program was not conducted optimally in term of knowledge and oral language proficiency development where the students perceived it was very important. In order to bridge the gap, discussion was arranged. As a result, mutual agreement between the teacher and the students was achieved. In order to materialize the goal of learning both the teacher and the students agreed upon: 1) using English as a medium of communication during the learning program, 2) learning activities were conducted through presentation and discussion, 3) it was highly expected that students came to the class on time, tolerance for late comers would only be 10 minutes, 4) it was highly required that students met $75 \%$ of attendance at minimum, in order to participate in the final exam, 5) Assignment must be submitted punctually based on the schedule, 6) students were endorsed to actively participate in the learning activities.
\end{abstract}

Keywords: classroom policies, discussion, speaking proficiency, knowledge development

\begin{abstract}
Abstrak
Tulisan ini bertujuan untuk menyajikan laporan hasil penelitian yang diperoleh melalui interviu mendalam dan diskusi antara guru dan siswa. Hasil dari interviu dan diskusi yang diperoleh tersebut kemudian akan digunakan sebagai landasan untuk merumuskan cara untuk meningkatkan kualitas suasana belajar yang lebih baik pada program belajar yang akan datang. Dari data yang terkumpul, dapat difahami bahwa kegiatan belajar sebelumnya dari perspektif mahasiswa dirasa belum terlaksana dengan optimal khususnya dalam aspek penguasaan ilmu dan kemampuan menggunakan bahasa target secara verbal. Untuk menjembatani hal tersebut, maka perlu dilaksanakan diskusi mendalam. Dari hasil diskusi tersebut diperoleh beberapa kesepakan yang diharapkan mampu untuk meminimalisir masalah yang muncul dalam kegiatan belajar mengajar yang diyakini dapat mengganggu upaya mencapai hasil belajar yang diharapkan. Untuk mencapai hasil belajar yang diharapkan baik guru maupun siswa sepakat untuk melaksanakan aturan-aturan yang telah disepakati bersama. : 1) menjadikan bahasa Inggris sebagai bahasa utama dalam kegiatan belajar mengajar, 2) aktifitas belajar dilaksanakan melalui presentasi dan diskusi, 3) terkait dengan kedisiplinan, para siswa diharapkan untuk hadir tepat waktu, toleransi keterlambatan yang diberikan tidak lebih dari 10 menit, 4) Sangat dianjurkan bagi setiap siswa untuk memenuhi prosentase kehadiran sekurang-kurangnya $75 \%$ sebagai syarat mengikuti ujian akhir, 5) Tugas yang diberikan wajib diserahkan tepat waktu sesuai dengan jadual, 6) Masing-masing siswa tergabung dalam kelas tersebut wajib untuk secara aktif mengambil bagian dalam proses kegiatan belajar mengajar.
\end{abstract}

Kata kunci: Kebijakan Kelas, Diskusi, Kemampuan Berbicara, Pengembangan Pengetahuan 


\section{INTRODUCTION}

Getting awareness of students in connection to the goal of education is undeniably necessary. Realizing, that learning success depends not only on the shoulder of a teacher as an agent of change, but also students as ones who need to develop. Teacher and students in term of classroom learning are partners working together to achieve particularly set educational goal. Therefore, they need to work collaboratively in order to materialize what is planned to achieve. In a real context, classroom is dynamic where things can go unpredictably. Teachers may experience from good things that support the running of the lesson they are teaching about or on the other way around, things may go completely different that students may behave unexpectedly due to matters going in or outside the classroom. Good behavior students may have will contribute benefit to the success of the program, however misbehaving that students do during the process of learning will certainly bring discomfort either to teacher or students participating in the program. In order to avoid the unexpected, presence of classroom rules or policies is required. Kelly (2016) argued that classroom policy is a method aimed at preventing students to unexpectedly behave negatively and providing ways to handle it. It is way to keep the students under-control during the class. Doyle, \& Carter (2016); Barker, R. G. (1963) confirmed that classroom policy or academic task, they name it, was proposed to show the situational structures that organize and direct thought and action which is materialized in a plan functioning as a tool that directs behaviors during participation in the setting. By reading the highlight, classroom policy seems to be essentially important for teachers, instructors and facilitators to which it underlines all aspects going in the classroom while teaching and learning are still in progress (First, 2014). In order to bring convenience in practice policies made must be able to accommodate the expectation of the learning itself. Not only is Classroom policy about how the learning materials administered by teachers to the students, but it will also deal with how mutual interaction between students and teachers are established within the educational processes (First, 2014). Classroom policy needs careful planning and thought to which it may involve the perspective of the students in relation to how the classroom activities are supposed to be set to meet the learning target as well as to bring convenience to all parties involved in the process. In order to meet the target, activities conducted must highly correspond to the curriculum fidelity, while in order to meet the convenience, clarity of the rules, transition, norms and expectation must be accommodated during the process of learning. However, things set above are not supposed to change the meaning to the teaching itself.

This research was conducted in a context where teachers met the problem about improving language quality of the students, mainly at spoken skill. With reference on the data collected from investigation, the primary matter encountered is on building learning environment that support students' knowledge development and students' involvement in using the English language. Another issue deals with cultural problem, students bring from their previous learning where reading, independent learning, and being aware of learning purpose itself are not yet perceived as essential matters they need to take seriously during the study. In addition to this, their fighting spirit is considerably low. It is reflected from the way they deal with the assignment and academic stuffs. Another factor to contribute to this less effective learning activity is suspected to be from the massive gap between the teachers and their students. Conventional behavior of some teachers who think that they are the only master in the class holding full power upon their students rather than being a friend to them sometimes has created such 
a danger that must be gradually minimized to support learning environment expected.

Design of the research was taken from the concept of Doyle, \& Carter (2016); Barker (1963) about the classroom policy in which they argued that classroom policy was proposed to show the situational structures that organize and direct thought and action, which is materialized in a plan functioning as a tool that directs behaviors during participation in the setting. In order to build awareness and bring the sense of ownership among the teachers and students, this model was then further developed by adopting the concept of participatory. Referring to its characteristics, participatory research has been perceived to help gain positive criticism from community expecting from a better change (Barton, A. C., Johnson V., \& The Students in Ms. Johnson's Grade 8 science classes, 2002). Liberman (1994) argues Participatory research has the purpose of creating learning community to which the participants will be encouraged to actively participate in the creation of the community rather than to be a passive listener. The participation itself is conducted democratically through the involvement of knowledge and endorsement of a constant construction and reconstruction of the boundaries. This process is considered important as the involvement is expected to bring commitment among all and to help facilitate in the process of achieving the goal of the learning. He further says that participatory research is essential to give teachers better understanding about their students and to enable the teachers themselves to respond the need for the learning and those involved while at the same time this is such a process of challenging the traditional concept of teaching (Liberman, 1994).

To end up the introduction, the goal of this research was to create classroom policy where students were included rather than excluded to create knowledge rather than traditionally thinking that the class belongs to the classroom teachers (Doyle \& Carter, 2016; First, 2014; Barker, 1963; Liberman, 1994). By doing this research, it was expected that this project would be able to reveal students' demand upon the setting of learning as well as find out solution to establish an effective learning program. In addition, to emerge the sense of belonging from all participants, to recognize what to do and what is not supposed to do and to let all be aware of the goal of the learning.

\section{METHOD}

\section{Research design}

This research belongs to participatory research intended both for academics and for those whose research result was intended for. Participatory research is widely recognized as an alternative philosophy from the social research that is commonly related to social transformation. In doing the project, researcher will get the research objects involved in order to collect information from the community and to set necessitated action that will likely be performed in order to improve the quality of the research object through predesigned treatment (Kemmis \& Mc'Taggart, n.d). Further, Liberman (1994) argues Participatory research has the purpose of creating learning community to which the participants will be encouraged to actively participate in the creation of the community rather than to be a passive listener. The participation itself is conducted democratically through the involvement of knowledge and endorsement of a constant construction and reconstruction of the boundaries. This process is considered important as the involvement expected to bring commitment among all and to help facilitate in the process of achieving the goal of the learning. He further says that participatory research is essential to give teachers better understanding about their students and to enable the teachers themselves to respond the need for the learning and those involved while at the 
same time this is such a process of challenging the traditional concept of teaching (Liberman, 1994). With the reference to participatory research theoretical framework, this research would make use of research participants as source of the information and serve the collected information to formulate mutual classroom policies.

\section{Setting and participant}

This study was carried out in a higher education setting involving classes taken from different levels in the department. There were around five hundred students in total studying at the department. However, only were two different classes consisting of 35 students each selected to participate in the research. The selection was conducted by referring to the need for the research and the access the researcher had. The two selected classes were indeed under the control of the researcher to which he was teaching the participating students in the theoretical programs.

\section{Data collection and analysis}

The research data were collected through recording the result in the interview and discussion among the teachers and the students. This interview was structurally held in order to gain comprehensive information in relation to their perception towards academic problems they were experiencing in the process achieving the learning goal of learning. Besides, this was also an attempt to turn up responses and suggestion towards their upcoming program setting. As the required data were collected, they were then analyzed, highlighted and brought up in a discussion in order to find solution on the academic matters they were suffering in the previous learning programs. Result in the interview and discussion was expected to be essential points needed to create classroom policies later applied to all participants involved in the program.

\section{FINDINGS AND DISCUSSION}

\section{Students' Response towards Previous Learning Programs}

Of the result in data collection, students generally perceived that the previous learning activities were going okay. However, in particular case, they found that the lesson was rather difficult to holistically understand in relation to the point of the program: "(...) the program was well executed, but sometimes we're still confused to understand the learning materials". Further, the students suggested that it would have been better if syllabus and discussion points per meeting were clearly made in the beginning of the program in order to enable them to get things prepared before class: "Supposed that points per meeting is informed prior to or in the beginning of the meeting, we can have the chance to better study before class, (...)". They thought that it was important that the subject they had was set not only theoretically but also in practice in order to support their language skill development and to extend their confidence to manage and speak in front of people: "we actually expected that we can clearly understand the benefit from joining this classes through the learning outline the teacher had (...). it was also beneficial if the subject was set not only theoretically but also in practice in order to support our language skill development and to extend our skill development in managing class as well as in doing public speaking, (...)”.

\section{How Learning Policies were Made to Support Learning Process}

From the interview, students said that when the teacher came to class, he already had the concepts of classroom policies he wanted to apply in the classroom. The policies would normally be stated in the first meeting of the program: "The teacher already owned the concept of classroom policies he planned to apply in the classroom (...). (...) it was commonly announced to the students in the first meeting". Further, they also stated that discussion related to policies between the teacher and the 
students rarely happened: "it was such a rare thing to do". On the other way around, they expect the discussion in order to negotiate the policies for mutual relationship: "It will be so much better, if discussion is accommodated (...)". However, in most cases, students preferred to keep silent rather than pointing ideas to conduct such discussion and received as it was the term and condition set by the teacher that in fact, they sometimes disagreed with the term and condition stated: "sometimes, we partly disagreed with the policies (...)". As the result, this could be suspected to be source of the problem that might bring negative impact to the implementation of the learning in the classroom.

\section{Response on the Impact of the Policies Set in the Previous Learning Programs}

With reference to the analysis result of the research, it was observed that although students perceived that the class was running okay, they still thought that their speaking ability still needed a lot of improvement, and they said that it was due to lack of exposure especially in the process of learning in the classroom. Therefore, more facilities to support the speaking skill was preferred: "The class was okay, but we need more space to practice our English (...)". Learning activities involved more Indonesian rather than English. The teacher sometimes conducted the class more in Indonesian: "(..) not whole time using English, Indonesian was applied more (...). the teacher sometimes used more Indonesian during bis teaching to us". They commented that systematic exposure was important to help students grow better in the skill they are learning. Teacher should have been more assertive in directing class and violating students should have got consequence from what he did: "We should have been forced more in using English, (...) such as doing presentation (...). (...) no sanction, the teacher just told the students that we needed to use English. (...) in fact, the teacher bimself sometimes used more Indonesian to English". Further, overseeing the response from the students, in general, they feel like to be instructed or be forced to obey the agreed policies. Therefore, role of teacher in term of selecting rules and teaching model as well as behaving as a role model to his students would be factor to determine the success of the learning.

\section{Response of the Students on the Assignments Provided during the Program}

In the previous learning programs the students had, the provided assignments included reading provided reference books, working on provided questions, or doing presentation: "(...) usually asked to read reference books, conduct discussion, work on questions or do presentation". The presentation was conducted by dividing the students into groups. Number of participant in the group adjusted to the number of the students in the class. It was normally between three to four people per group: "(...) in the presentation, we were divided into groups, one group consisted of three to four people (...)". Based on the data from the interview, turn to do the presentation was determined in the first meeting after discussing the learning contract: “(...) had been determined in the first meeting after listening to the explanation related to learning contract". As the turn selection was completed, the result would then be immediately announced to get to know which group was going to perform when. This presentation activity was not demanding clear format organizing rules for doing the presentation, to which it was supposed to include how the presented materials should be organized and presented: “(..) to the slide, the teacher did not let us know, the format used was up to the students". Rules for presentation did not restrict the students from just thoroughly reading books or the slides they made: "(...) for some cases, we just simply read." Other than presentation, discussion was also conducted. It was related to the provided learning topics and after the discussing time was over, the assigned topic would be discussed together in class: "for discussion, we were divided into groups, assigned a topic we need to learn and 
discuss with whole members in the class after". As a follow up, students were asked to answer further questions that was due on the next meeting: "we were asked to read or do other related assignments that were due on the next meeting".

Things in connection with assigning process seemed to have been well conducted, however in one point related to the presentation model, from the perspective of the researcher, the activity should have avoided direct assigning (who will present what and when). In most practices, supposed that if it was conducted without careful control from the teacher, the students would likely be found to learn the material to which they were only assigned to, and neglect the rest learning materials they were supposed to learn as well. It was no wonder that the class adopting this presentation model was commonly less interactive and beneficial. Further, students seemed not to take serious responsibility to participate and consistently attend to the program, this was admitted from their attendance on the scheduled time. Things would get worse when some teachers thought that the students were mature and knowing what to do and what their responsibility as a student was. This was such a thing that possibly impacted to the students' final understanding towards the subject they were learning. Further, assigning who was going to present what and when was supposed to be kept secret until the time came. As a result, all students would try to get themselves ready to do the presentation as nobody knew who would present on the day. Presenter of the day was supposed to be selected randomly right before the presentation began. By observing, the statements, it might be synthesized that providing detail and clear guidance to the implementation of the program in the beginning of the class is important. Getting the students to contribute their thought and confirm their understanding and awareness on the agreed regulation must be set before things were implemented. In order to support the success of the program, things to bring up in the teacher and students discussion were supposed to include at least information on how the presentation slide should be organized (what is and what is not supposed to be there); the language used in the activity was supposed to be in English, not only in the presentation, but also in all learning activities during the program, including $\mathrm{Q}$ and $\mathrm{A}$ in the seminar session; the presentation slides had to contain points rather than written text. With this, everyone participating was expected to realize what to do and what consequence they might have if they broke the rules. Besides, it was believed that rules as a result in discussion would bring the students positive endorsement to get themselves ready in term of language and knowledge on the subjects they were learning about.

\section{Need and Expectation of the Students towards the Program}

Of the data, it was observed that students were expecting better learning program that enabled them to improve their knowledge and language proficiency. The future learning program had to be able to accommodate development of both, knowledge and language skills. Therefore, learning involving more practices are preferable. Further, the interview and discussion held among students and the teacher had generated things that would be included in the policies to organize the learning programs to which it would function as the basis to organize the behaviors of all participants involved. From the discussion, it was confirmed that both students and teacher agreed to include the following matters in the policies; (1) learning activities students would do in the classroom, (2) language allowed to use during the process of teaching and learning, (3) minimum attendance in order to participate in the final exam, (4) learning tools needed to be available during the program, (5) tardiness, (6) matters to include to calculate the final 
score. Things just mentioned would then be elaborated into clearer information.

\section{Result in Interview and Discussion}

From the result in the interview and discussion, it was found that both students and teacher agreed that students had to be present before the class started. Maximum tolerance for tardiness would only be 10 minutes after the class started. In order to participate in the final exam, they had to meet the minimum requirement of $75 \%$ or equal to 3 times. Those who could be 100\% present during the program would be awarded additional point useful to optimize their final score. No tolerance, for those whose presence was below $75 \%$ either to participate in the final exam or to get their final score issued. The result in the discussion and interview indicated that students preferred to have class adopting students centered rather than teachers centered. As stated previously, students needed more exposure in order to improve their knowledge and language performance. Supposed that the subjects related to theory, they expected that it could be set in discussion or presentation. In response to this, the learning activities were set by adopting the concept of student centered learning where students would be demanded to understand things related to their learning through reading, thinking critically, discussing and doing trial and error. Realizing that ability of each student was different, discussion was perceived to be important to facilitate knowledge sharing. To achieve the prearranged academic goal, the learning activities was set in presentation (seminar) and discussion. No mother language was allowed. English was the only language to use in the classroom. To make sure that everyone would study the assigned materials, the taking of the presentation turn would randomly be executed, therefore nobody knew who would get the turn to present on the day where the program was conducted. Further, everyone participating in the program should have got himself ready with materials to present. This presentation would demand the presenter to well explain the materials, just reading text in the slides would not be allowed, instead, their presented slides had to include points only. Ability to orally explain and well handle questions from audiences would be such consideration to give optimum score. This activity would be organized into: 10 minutes for preparation, 30 minutes for presentation, 30 minutes for Q\&A and the last 30 minutes to draw conclusion upon the result in the discussion among the students. Before the class was dismissed, the teacher would instruct the students to make summary upon things discussed during the meeting and be submitted on the next meeting. For those who actively participated in the program by adding more information and providing clarification upon the answers/ explanation of their classmates would be valued differently. On the other hands, for those who were passive, they were instructed to multiply the assignments three times. To support the class activities, each student was obliged to bring his handout and monolingual dictionary. For those who failed to do this would be dismissed from class.

\section{Classroom Policies}

As discussion was ended up and the points had been agreed by all involved, the following policies were stipulated in order to be reference to conduct the program; (1) Commitment to use English as the language to communicate in the classroom, including but not just being limited to presentation. (2) During the presentation, presenters were prohibited to just read either from slides or books they were using as reference. Slides for presentation had to accommodate points to deliver instead of long text taking from books. (3) Monolingual dictionary and handout had to be available during the class. Those who could not meet the requirement would not be admitted to participate the class. (4) In order to 
participate in the final exam, students were obliged to meet the requirement of $75 \%$ of attendance at minimum. Having the attendance lesser than $75 \%$, the students would receive consequence for not being allowed to participate the class. Further to this, their final score would also not be issued. (5) Middle exam and final exam would be a comprehensive test. (6) Maximum tolerance for tardiness was 10 minutes after the class started. (7) Submission of the assignment had to be conducted in accordance with the instruction from the teacher, violation would result in score reduction. (8) Learning activities in the classroom would be centered to the students. Most of the activities would require the students to present the assigned materials orally with reference to the rules set up before. This presentation would be conducted in a group, consisting of two and maximum three members in it. As the presentation would be completed, there would be time for Q\&A and then proceeded with discussion. It was such an obligation for each students to read, understand and get their presentation slides ready before class. As in fact, nobody knew who was coming for presentation. The presentation turn would be determined at the day where the presentation activity would be conducted. For those who could not perform, as the selection would have been made, they would miss the chance and would never get the second turn. This issue would impact to the score they were going to receive in the end of the program. (9) In order to get optimum score, the audience would be encouraged to actively participate in the program through questioning, clarifying and adding more information related to the discussed topics. To ensure that the process would run as expected, students who actively participated would be awarded additional points and just instructed to make only one summary based on the discussed topic and for those who were passive, as a consequence, they would be assigned to make the summary three times.

\section{CONCLUSION}

There was a need to improve the current system in relation to classroom management where policies made must be able to accommodate the expectation of the learning and learners themselves. It was revealed that students demanded more than what they had in the previous programs. Therefore, they were expecting that the future course program was expected to be able to facilitate the activities that can help them to improve their knowledge and their oral language proficiency.

\section{REFERENCES}

Barker, R. G. (1963). On the nature of the environment. Journal of Social Issues, 21, 17-38.

Barton, A. C., Johnson V., \& The Students in Ms. Johnson's Grade 8 science classes (2002). Truncating Agency: Peer Review and Participatory Research. Research in Science Education, 32, 191-214.

Doyle, W., \& Carter, K. (2016). Academic Tasks in Classrooms Academic Tasks in Classrooms, 6784(June). http://doi.org/10.1080/03626784.19 $\underline{84.11075917}$

Kelly, B. M. (2016). Definition of Classroom Management, 4-7. Retrieved from http://712educators.about.com/od/c lassroomhelpers/g/Definition-OfClassroom-Management.htm

First, P. (2014). Classroom Management Strategies Classroom Management, 1-14.

Kemmis, S. and McTaggart, R. (n.d). Participatory Action Research: Communicative and The Public Sphere. Retrieved from: 
http://citeseerx.ist.psu.edu/viewdoc/ download?doi $=10.11 .473 .4759 \&$ rep Erep1\&type $=$ pdf

Lieberman, A. (1994). Transforming urban schools: Building knowledge and building community. In M. Fine (Ed.), Chartering urban school reform: Reflections on public bigh schools in the midst of change (pp. 204-207). New York: Teachers College Press. 